\title{
Laboratory and Field Evaluation of a Cypermethrin- Based Insecticide for the Control of Alphitobius \\ Diaperinus Panzer (Coleoptera: Tenebrionidae) and \\ Its In-Vitro Effects on Beauveria Bassiana Bals. Vuill. (Hypocreales: Cordycipitaceae)
}

ISSN 1516-635X Jul - Sept 2016 / v.18 / n.3 / 371-380

http://dx.doi.org/10.1590/1806-9061-2015-0115

-Author(s)

\section{Oliveira DGPI \\ Cardoso RR" \\ Mamprim AP" \\ Angeli LF"}

Federal University of Technology/ UTFPR, Biology Department, 85892000, Santa Helena, Paraná, Brazil. Email: daianguilherme@yahoo.com.br

" State University of Western Paraná, Laboratory of Agricultural Biotechnology, 85814110, Cascavel, Paraná, Brazil

\section{-Mail Address}

Corresponding author e-mail address Daian Guilherme Pinto Oliveira

Prolongamento da Rua Cerejera, s/n, Bairro São Luiz

85892000. Santa Helena, Paraná, Brazil Tel: $\quad 55453268-8820$

Email: daianguilherme@yahoo.com.br daiang@utfpr.edu.br

\section{aKeywords}

Entomopathogenic Fungi; Integrated Pest Management; Broiler Chickens; Insecticide Selectivity.

\section{ABSTRACT}

The control of Alphitobius diaperinus is based mainly on chemical insecticides, and the indiscriminate and incorrect use of these products has led to failures in insect control. Thus, it is important to monitor the efficiency of the products available on the market and to develop alternative insect control strategies. The present study evaluated the effect of a new product (cypermethrin-6\%) under laboratory and field conditions and assessed its in-vitro compatibility with the fungus Beauveria bassiana (Unioeste 4 isolate). Its efficiency in dry powder and wettable powder formulations was also assessed in the laboratory through comparison with a similar insecticide (cypermethrin-5\%) at five different concentrations. The field assays were conducted in two commercial broiler breeder houses (Treated and Control), applying the new product on the litter at the manufacturer's recommended concentration (RC). Germination, vegetative growth, conidial production, number of colony forming units (CFUs) and insecticidal activity of the fungus were used to evaluate the compatibility of the insecticide. The effects of the cypermethrin- $6 \%$ product and cypermethrin-5\% were equivalent in the laboratory, and the new product exhibited better performance at lower concentrations $(1 / 4 R C, 1 / 8 R C)$. The strategy applied in the field reduced the insect population in up to $96 \%$ after 75 days. Additionally, all concentrations of cypermethrin-6\% were compatible with the fungus under the evaluated in-vitro conditions. Therefore, the new product is considered selective for $B$. bassiana. Further studies are necessary to assess its compatibility under field conditions, consolidating this strategy as a viable alternative for managing this pest.

\section{INTRODUCTION}

The lesser mealworm, Alphitobius diaperinus Panzer (Coleoptera: Tenebrionidae), is a secondary pest of stored grains. The introduction of $A$. diaperinus in poultry houses most likely occur through feed, and it quickly adapted to this environment due to the abundance of shelter and food (Pacheco \& Paula, 1995; Lopes et al., 2006).

When $A$. diaperinus is present in poultry houses, the birds feed on the larvae and adults and thus cease to consume a balanced diet, reducing feed efficiency (Chernaki-Leffer et al., 2001; Japp et al., 2010). The occurrence of $A$. diaperinus is also detrimental for the health status of rearing facilities, as it is a vector of viruses, bacteria, fungi, protozoa and helminths that cause significant diseases in poultry (Chernaki-Leffer et al., 2002; Bates et al., 2004; Segabinazi et al., 2005; Hazeleger et al., 2008; Agabou \& Alloui, 2010; Chernaki-Leffer et al., 2010; Alborzi \& Rahbar, 2012; Crippen et al., 2012), including salmonellosis, a disease of great importance, especially in broiler-breeder production. 
A. diaperinus has a high reproduction rate and feeds on poultry feed, droppings and dead birds when it becomes established in poultry houses. The adults display cryptic habits, making pest control difficult and causing economic losses to poultry farmers (Silva et al., 2001, 2005; Bicho et al., 2005; Lopes et al., 2007).

Management practices, such as reducing the number of flocks of chickens reared on reused poultry litter, paving floors with concrete or cement, and using good management practices (GMP) are recommended for reducing $A$. diaperinus populations (Bellaver et al., 2003; Avila et al., 2007; Silva et al., 2007). However, some of these management practices are timeconsuming, requiring poultry houses to remain empty for an extended period of time, and compromising the annual farm revenues.

The application of pyrethroid and organophosphate insecticides is the most common control practice for managing $A$. diaperinus adopted by the poultry industry worldwide (Lambkin, 2005; Alves et al., 2010). This type of chemical control is often preventive (Oliveira et al., 2014) and it is performed during the short time interval between the removal of one flock of chickens and the introduction of another. Chemical control is the most cost-effective strategy for poultry producers in the short term.

In addition to applying chemical insecticides at the correct concentration as part of an adequate control strategy, studies evaluating the efficiency of the products and formulations used directly inside poultry houses are also fundamental for insect control (Salin et al., 2003; Lambkin, 2005; Santos et al., 2009; Mustac et al., 2013), as application failures may occur, leading to unsuccessful control. Furthermore, prolonged use of a same insecticide at dosages exceeding the recommended values has resulted in the selection of resistant insects (Japp et al., 2010 Chernaki-Leffer et al., 2011).

The fungus Beauveria bassiana (Bals.) Vuill. (Ascomycota: Cordycipitaceae) is an alternative strategy for the control of the lesser mealworm. This entomopathogenic fungus occurs naturally in poultry houses (Steinkraus et al., 1991; Alves et al., 2005) and presents great potential for pest control (Oliveira et al., 2014). Moreover, this fungus has been shown to be effective both under laboratory conditions (Alexandre et al., 2006; Rohde et al., 2006; Alves et al., 2008) and in field assays (Alves et al., in press).

Lesser mealworm populations are difficult to control in poultry houses. Therefore, the combined use of chemical and biological insecticides may be adopted as part of a pest management program and it is a potentially viable strategy. According to Wolf et al. (2015), the combined use of different methods for the control of A. diaperinus populations can provide benefits, such as allowing reduced use of chemical insecticides, consequently reducing their detrimental effects on the environment, and on human and animal health.

However, some chemical insecticides may affect the biological parameters of entomopathogenic fungi (e.g., their viability, vegetative growth, and conidiogenesis) and change their genetic composition, consequently reducing their virulence and infection capacity (Alves et al., 1998a).

This study aimed at evaluating the effect of a new cypermethrin-6\%-based insecticide recommended for the control of the lesser mealworm under both field and laboratory conditions and to determine its in-vitro compatibility with the $B$. bassiana Unioeste 4 isolate. The efficacy of the insecticide in dry powder and wettable powder formulations was also assessed in the laboratory by comparing it with a similar insecticide (cypermethrin-5\%) at five different concentrations.

\section{MATERIALS AND METHODS}

\section{LABORATORY ASSAYS}

\section{Contact activity of cypermethrin-based insecticides against Alphitobius diaperinus}

Tested insects. The insecticidal activity of the products was evaluated through direct contact using lesser mealworm adults collected from a commercial poultry farm located in Cascavel, State of Paraná, Brazil. In total, 250 insects per treatment, with five replicates each, were used (Alves et al., 2010).

Tested products. The cypermethrin-based products were Agnis ${ }^{\circledR}$ WP (wettable powder) (active ingredient 60 g/kg) (Dominus Química Ltda., Jandaia do Sul, State of Paraná, Brazil), Agnis ${ }^{\circledR}$ DP (dry powder) (a.i. $60 \mathrm{~g} / \mathrm{kg}$ ) (Dominus Química Ltda.), and Vetancid ${ }^{\circledR}$ DP (a.i. $50 \mathrm{~g} /$ kg) (Vetanco do Brasil Ltda., Chapecó, State of Santa Catarina, Brazil). According to the manufacturers, all products include citronella oil for its repellent effect.

Bioassay. Groups of insects (replicates) were kept in plastic containers $\left(152 \mathrm{~cm}^{2}\right)$, and the products were applied. Each product was evaluated at five concentrations: the recommended concentration $(R C)$ and double $(2 R C)$, half $(1 / 2 R C)$, one-fourth $(1 / 4 R C)$ and one-eighth $(1 / 8 R C)$ of the $R C$. The concentration recommended by the manufacturers was standardized for an area of $500 \mathrm{~m}^{2}$ regardless of the formulation, corresponding to $3 \mathrm{~g}$ of the product per $\mathrm{m}^{2}$, as follows: $\mathrm{RC}=45.6 \mathrm{mg}$ of product/replicate; $2 \mathrm{RC}=91.2 \mathrm{mg}$; $1 / 2 R C=22.8 \mathrm{mg} ; 1 / 4 R C=11.4 \mathrm{mg} ; 1 / 8 R C=5.7 \mathrm{mg}$. 
The products in powder form (DP) were directly sprinkled in the plastic containers, while the wettable powder product was prepared in water, standardizing the aforementioned amounts to a final volume of 1 $\mathrm{mL}$, which was sprayed onto the insects in a Potter Spray Tower (Burkard Manufacturing Co. Ltd.). Thirty minutes after application, insects were transferred to Petri dishes containing poultry feed and incubated in a climate chamber $\left(26 \pm 1^{\circ} \mathrm{C}\right.$; 14 -hour photoperiod). Mortality was evaluated 10 days after treatment.

Compatibility tests ( $B$. bassiana Unioeste 4 isolate $\times$ WP cypermethrin- $6 \%$ product)

Fungal isolate. The $B$. bassiana Unioeste 4 isolate of the entomopathogenic fungi collection of the Laboratory of Agricultural Biotechnology of the State University of West Paraná (Unioeste) was used because it exhibits a high virulence against both larval and adult lesser mealworms (Rohde et al., 2006). The fungus was grown in sporulation medium (SM) (20 g agar, $5 \mathrm{~g}$ yeast extract, $4.6 \mathrm{~g}$ salt mixture, $10 \mathrm{~g}$ glucose and 1000 $\mathrm{mL}$ distilled water) (Alves et al., 1998b) and incubated for seven days at $26 \pm 2^{\circ} \mathrm{C}$ under a $12 \mathrm{~h}$ photoperiod until conidiogenesis, and stored at $-10^{\circ} \mathrm{C}$.

Evaluated fungal parameters: The effects of the product WP cypermethrin-6\% (at RC, 2RC, and $1 / 2 R C$ ) on the Unioeste 4 isolate were evaluated by classifying its toxicity according to Rossi-Zalaf et al. (2008). Four replicates per treatment were used in all tests. The toxicity index was calculated using the parameters viability (conidial germination), colony diameter (vegetative growth), and conidial

production. $\mathrm{TI}=\frac{47[\mathrm{VG}]+43[\mathrm{SP}]+10[\mathrm{GER}]}{100}$, where $\mathrm{TI}$

= toxicity index; GER (viability) = conidial germination percentage after $16 \mathrm{~h}$; VG = colony vegetative growth percentage after seven days relative to the control; and $\mathrm{SP}=$ colony conidial production after seven days compared with the control. The values of GER, VG and SP were previously corrected relative to the respective control treatments (fungal isolate without insecticide). $\mathrm{TI}$ values were classified as toxic (0 to 41$)$, moderately toxic (42 to 66) or compatible (above 66 ).

The effects of the WP cypermethrin- $6 \%$ product on the number of colony forming units (CFUs) and on the insecticidal activity of the fungal isolate were also evaluated.

Germination (GER). A 300- $\mu \mathrm{L}$ volume of a conidial suspension $\left(1 \times 10^{6}\right.$ conidia $\left./ \mathrm{mL}\right)$ was inoculated in the center of a RODAC plate containing $5 \mathrm{~mL}$ of potato dextrose agar (PDA) medium plus antibiotic (Oliveira,
2009). A $250-\mu \mathrm{L}$ volume of the product was pulverized using a manual airbrush-type atomizer on the plates, which were then incubated for $16 \mathrm{~h}$ at $26 \pm 2^{\circ} \mathrm{C}$ under a $12 \mathrm{~h}$ photoperiod. The numbers of germinated and non-germinated conidia were counted under an optical microscope. Approximately 200 conidia per plate were recorded.

Vegetative growth (VG). The fungus was inoculated at three points on the surface of PDA culture medium in Petri dishes and then incubated at $26 \pm 2^{\circ} \mathrm{C}$ under a $12 \mathrm{~h}$ photoperiod for 48 hours. The chemical insecticide was subsequently sprayed on the plates as previously described. The plates were incubated under the same conditions for 7 days. The mean diameter of the colonies was obtained from two measurements using a pachymeter.

Production of conidia (SP). Two colonies from each plate from the vegetative growth assay were individually cut from the medium and transferred to sterile glass tubes with $10 \mathrm{~mL}$ of Tween 80 solution $(0.01 \%)$, followed by stirring until conidial detachment. The conidia were counted in a Neubauer chamber after serial dilutions.

Colony forming units (CFU). A total of $100 \mu \mathrm{L}$ of the suspension $\left(1 \times 10^{3}\right.$ conidia $\left./ \mathrm{mL}\right)$ was inoculated and spread on Petri dishes containing PDA culture medium. The insecticide was sprayed immediately after, as previously described. The plates were incubated for 5 days at $26 \pm 2^{\circ} \mathrm{C}$ under a $12 \mathrm{~h}$ photoperiod. Colonies were subsequently counted.

Fungal insecticide activity. In order to evaluate the effect of the chemical insecticide on the insecticidal activity of the fungus $B$. bassiana Unioeste 4, the isolate was inoculated into plates containing sporulation medium. After 48 hours, $1 \mathrm{~mL}$ of the product at each concentration was sprayed on the culture medium as previously described. The plates were incubated for seven days at $26 \pm 2^{\circ} \mathrm{C}$ under a $12 \mathrm{~h}$ photoperiod. The conidia were sampled by scraping the surface of the culture medium and transferred to glass tubes. Suspensions were prepared at a concentration of $1 \times 10^{9}$ conidia $/ \mathrm{mL}$, and adult insects were immersed in $1 \mathrm{~mL}$ of the suspension for 10 seconds, following Rohde et al. (2006). Five replicates with 50 insects were performed (250 insects per treatment).

\section{FIELD ASSAY}

\section{Control of A. diaperinus with cypermethrin- based insecticide}

Poultry house description. The study was conducted in two commercial broiler-breeder houses 
(Control and Treated) located in Cascavel, State of Paraná, Brazil, managed under a 'dark house' system. Both poultry houses had concrete floors, central extractor hoods, automated trough feeders and environmental-control systems, and the poultry litter consisted of wood shavings. Each poultry house had an area of $2800 \mathrm{~m}^{2}$ (14 m width $\times 200 \mathrm{~m}$ length), and housed approximately 22,400 birds for six-month periods.

Insecticide treatment. The commercial product (DP cypermethrin-6\%) was applied on the poultry litter using a motorized atomizer at $3 \mathrm{~g} / \mathrm{m}^{2}$, totaling $8.4 \mathrm{~kg}$ of product per treatment. Reapplications were performed at 30 and 60 days after the initial treatment. The control poultry house did not receive any insecticide application.

Insect sampling. The lesser mealworm populations were evaluated prior to application and 15 days after each insecticide application (15, 45 and 75 days after the beginning of the experiment). Twelve points were determined along the poultry house, following Godinho \& Alves (2009). At each point, sub-samples consisting of $300 \mathrm{~mL}$ of poultry litter were collected along the low walls, pillars and feeders at each site to count live insects (larvae and adults). Each point was considered a replicate and consisted of a set of the three sub-samples.

\section{Statistical Analyses}

Data were tested for normality using the ShapiroWilk test. Laboratory data were submitted to analysis of variance (ANOVA), and means were compared by Tukey's test, with $p<0.05$ being considered significant. The analyses were conducted using the software Sisvar (Ferreira, 2011). When necessary, the average percentages were transformed by $\operatorname{arcsen} \sqrt{\mathrm{x} / 100}$.

Mean insect populations in the four evaluations performed in the same poultry house were compared using the Wilcoxon test $(p<0.05)$. The Mann-Whitney test $(p<0.05)$ was employed to compare the evaluated poultry houses (insecticide-treated and control) using the software Bioestat version 5.3 (Ayres \& Ayres, 2007).

\section{RESULTS}

\section{Contact activity of cypermethrin-based insecticides at different concentrations}

The cypermethrin-6\% (both formulations) and DP cypermethrin-5\% products exhibited equivalent efficiencies. However, cypermethrin-6\% was significantly $(F=346.55$; C.V. $=3.1 \%)$ more efficient at lower concentrations than DP cypermethrin-5\%, when the doses of $1 / 4 R C$ were compared with $1 / 4 R C$ and $1 / 8 R C$ with $1 / 8 R C$, respectively (Table 1 ).

The DP cypermethrin-5\% product showed a similar efficiency at $2 R C, R C$ and $1 / 2 R C$, but mortality was reduced at $1 / 4 R C(92.4 \%$ mortality) and $1 / 8 R C(66.8 \%$ mortality) (Table 1).

The efficacy of the cypermethrin- $6 \%$ product in the DP formulation was similar among the different concentrations studied, and the maximal effect on insect mortality was observed even at a concentration eight times lower than that recommended by the manufacturer. Only the lowest concentration of cypermethrin- $6 \%$ in the WP formulation $(1 / 8 R C)$ presented inferior results, causing $92.4 \%$ insect mortality, whereas the other concentrations resulted in $100 \%$ insect mortality. The results obtained at $1 / 8 R C$ for cypermethrin-6\% was not significantly different between the DP and WP formulations (Table 1).

Table 1 - Mortality (\%) of adult lesser mealworms (Alphitobius diaperinus) 10 days after the application of cypermethrin-based chemical insecticides under laboratory conditions $\left(26 \pm 2^{\circ} \mathrm{C} ; 14 \mathrm{~h}\right.$ photoperiod).

\begin{tabular}{lcc}
\hline Product & Concentration $^{*}$ & $\%$ Mortality \\
\hline Control & - & $8.8 \pm 1.50 \mathrm{~d}$ \\
\hline & $2 \mathrm{RC}$ & $100.0 \pm 0.00 \mathrm{a}$ \\
& $\mathrm{RC}$ & $99.6 \pm 0.40 \mathrm{a}$ \\
Dry Powder & $1 / 2 \mathrm{RC}$ & $98.8 \pm 0.49 \mathrm{a}$ \\
(cypermethrin-5\%) & $1 / 4 \mathrm{RC}$ & $92.4 \pm 1.17 \mathrm{~b}$ \\
& $1 / 8 \mathrm{RC}$ & $66.8 \pm 3.93 \mathrm{C}$ \\
\hline & $2 \mathrm{RC}$ & $100.0 \pm 0.00 \mathrm{a}$ \\
& $\mathrm{RC}$ & $100.0 \pm 0.00 \mathrm{a}$ \\
Dry Powder & $1 / 2 \mathrm{RC}$ & $100.0 \pm 0.00 \mathrm{a}$ \\
(cypermethrin-6\%) & $1 / 4 \mathrm{RC}$ & $100.0 \pm 0.00 \mathrm{a}$ \\
& $1 / 8 \mathrm{RC}$ & $96.4 \pm 1.47 \mathrm{ab}$ \\
\hline & $2 \mathrm{RC}$ & $100.0 \pm 0.00 \mathrm{a}$ \\
& $\mathrm{RC}$ & $100.0 \pm 0.00 \mathrm{a}$ \\
Wettable Powder & $1 / 2 \mathrm{RC}$ & $100.0 \pm 0.00 \mathrm{a}$ \\
(cypermethrin-6\%) & $1 / 4 \mathrm{RC}$ & $100.0 \pm 0.00 \mathrm{a}$ \\
& $1 / 8 \mathrm{RC}$ & $92.4 \pm 1.94 \mathrm{~b}$ \\
\hline CV (\%) & & 3.1 \\
\hline
\end{tabular}

Means ( \pm SEM) followed by the same letter were not different by Tukey's test $(p<0.05)$. Cypermethrin-5\% dry powder = Vetancid ${ }^{\circledR}$; cypermethrin- $6 \%$ dry powder and wettable powder $=$ Agnis $^{\circledast}{ }^{*} \mathrm{RC}=$ recommended concentration; $2 \mathrm{RC}=$ double $\mathrm{RC} ; 1 / 2 \mathrm{RC}$ $=$ half $R C ; 1 / 4 R C=$ one-fourth $R C ; 1 / 8 R C=$ one-eighth $R C$. The product concentration recommended by the manufacturers was standardized, regardless of the formulation,

to $3 \mathrm{~g} / \mathrm{m}^{2}$. Average percentages were transformed by $\operatorname{arcsen} \sqrt{\mathrm{x} / 100}$ for statistical analyses.

\section{Compatibility tests}

The cypermethrin-6\% product affected (either positively or negatively) all of the fungal parameters evaluated for the toxicity index, showing that product affects the germination, vegetative growth and conidial production of the $B$. bassiana Unioeste 4 isolate (Table 2). 
Table 2 - Biological parameters and compatibility of the fungus Beauveria bassiana (Unioeste 4) with different concentrations of the cypermethrin- $6 \%$ wettable powder chemical insecticide under laboratory conditions $\left(26 \pm 2^{\circ} \mathrm{C} ; 12 \mathrm{~h}\right.$ photoperiod).

\begin{tabular}{|c|c|c|c|c|}
\hline Treatment & Viability (\%) & Diameter $(\mathrm{cm})$ & Conidial Production $(\times 106 / \mathrm{mL})$ & $T I^{*}$ \\
\hline Unioeste 4 (without insecticide) & $98.2 \pm 0.3 a$ & $2.0 \pm 0.03 b$ & $38.2 \pm 1.7 a$ & - \\
\hline Unioeste $4\left(2 R C^{*}\right)$ & $69.7 \pm 1.6 c$ & $2.6 \pm 0.05 a$ & $26.0 \pm 3.6 b$ & $96.2(\mathrm{C})$ \\
\hline Unioeste 4 (RC) & $74.9 \pm 2.2 c$ & $2.7 \pm 0.06 a$ & $25.4 \pm 4.0 \mathrm{~b}$ & 98.9 (C) \\
\hline Unioeste $4(1 / 2 R C)$ & $91.0 \pm 0.7 b$ & $2.5 \pm 0.07 \mathrm{a}$ & $14.8 \pm 2.8 b$ & $83.8(C)$ \\
\hline CV $(\%)$ & 3.7 & 4.9 & 27.0 & - \\
\hline
\end{tabular}

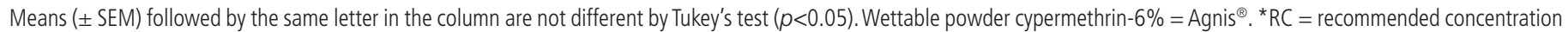
of insecticide; $2 R C=$ double $R C ; 1 / 2 R C=$ half $R C$. The product concentration recommended by the manufacturers was standardized, regardless of the formulation, to $3 \mathrm{~g} / \mathrm{m}^{2}$. ${ }^{*} T o x i c i t y$ index according to Rossi-Zalaf et al. (2008); TI values ranging from 0 to $41=$ toxic; 42 to $66=$ moderately toxic; above $66=$ compatible (C). Average percentages were transformed

by $\operatorname{arcsen} \sqrt{\mathrm{x} / 100}$ for statistical analyses.

At $\mathrm{RC}$ and $2 \mathrm{RC}$, the product significantly reduced conidial viability $(F=91.6$; C.V. $=3.7 \%)$, resulting in germination values of $74.9 \%$ and $69.7 \%$, respectively, relative to the control. A reduction in conidial viability was also observed at $1 / 2 R C$, but it was less marked, resulting in $91 \%$ germination.

Mean colony diameter increased relative to the control group at all tested product concentrations $(F=26.4 ;$ C.V. $=4.9 \%)$ and did not differ among concentrations. Conidial production was negatively affected and decreased at all evaluated concentrations $(F=27.0 ;$ C.V. $=9.2 \%)$

The toxicity index $(T)$ values obtained for the $2 R C$, $\mathrm{RC}$ and $1 / 2 \mathrm{RC}$ treatments were 96.2, 98.9 and 83.8, respectively. According to Rossi-Zalaf et al. (2008), $T$ values ranging from 0 to 41 are considered toxic, while those from 42 to 66 are considered moderately toxic, and those above 66 are considered compatible. Therefore, all of the tested concentrations of this chemical product are compatible with the fungus under the conditions evaluated in this study (Table 2).

\section{Effects on the number of colony forming units and fungal insecticide activity}

Mean number of colony forming units did not differ significantly among the control and the tested insecticide concentrations ( $F=2.7 ;$ C.V. $=10.1 \%$ ). This finding indicates that the insecticide did not affect this parameter (Table 3).

Additionally, the total mortality of $A$. diaperinus caused by the fungus was not significantly affected by the chemical insecticide $(F=2.0 ; C . V .=4.1 \%)$, with values above $94 \%$ being recorded. However, the confirmed mortality revealed that the product (insecticide) exerted a negative effect on the fungus at $2 \mathrm{RC}(F=4.5 ; C . V .=3.7 \%)$, presenting a lower value relative to the control group (Unioeste 4 without insecticide) (Table 3).

\section{FIELD ASSAY}

\section{Control of $A$. diaperinus with the cypermethrin- $6 \%$ insecticide}

The treatment with the DP cypermethrin-6\% product at $3 \mathrm{~g} / \mathrm{m}^{2}$ (three applications at 30-day intervals) was effective in causing mortality of lesser mealworms in the evaluated poultry houses, reducing the population by up to $96 \%$ after 75 days (Table 4 ).

The insect populations were similar in the control and treated poultry houses during the pre-treatment phase, exhibiting an average of 6.0 and 9.7 insects per sampling point, respectively. In the other assessments,

Table 3 - Effects of the cypermethrin-6\% wettable powder insecticide (different concentrations) on the number of colony forming units and the insecticidal activity of the fungus Beauveria bassiana (Unioeste $4 ; 1 \times 10^{9}$ conidia/mL) against Alphitobius diaperinus adults under laboratory conditions $\left(26 \pm 2^{\circ} \mathrm{C} ; 12 \mathrm{~h}\right.$ photoperiod).

\begin{tabular}{|c|c|c|c|}
\hline \multirow{2}{*}{ Treatment } & \multirow{2}{*}{$\mathrm{CFU} / \mathrm{mL}$} & \multicolumn{2}{|c|}{ Mortality of $A$. diaperinus (\%) } \\
\hline & & Total & Confirmed \\
\hline Unioeste 4 (without insecticide) & $112.6 \pm 2.50 a$ & $99.2 \pm 0.49 a$ & $98.4 \pm 0.75 a$ \\
\hline Unioeste 4 (2RC) & $124.0 \pm 7.92 \mathrm{a}$ & $94.0 \pm 2.00 \mathrm{a}$ & $91.2 \pm 1.74 b$ \\
\hline Unioeste $4(\mathrm{RC})$ & $129.2 \pm 3.10 a$ & $95.2 \pm 2.73 \mathrm{a}$ & $93.2 \pm 2.33 a b$ \\
\hline Unioeste $4(1 / 2 R C)$ & $111.0 \pm 6.12 a$ & $98.4 \pm 0.75 a$ & $97.2 \pm 1.02 a b$ \\
\hline CV (\%) & 10.1 & 4.1 & 3.7 \\
\hline
\end{tabular}

Means $\left( \pm\right.$ SEM) followed by the same letter in the column are not different by Tukey's test $(p<0.05)$. Wettable powder cypermethrin- $6 \%=$ Agnis ${ }^{\circledR}$. RC $=$ recommended concentration of insecticide; $2 R C=$ double $R C ; 1 / 2 R C=$ half $R C$. The product concentration recommended by the manufacturers was standardized, regardless of the formulation, to $3 \mathrm{~g} / \mathrm{m}^{2}$. The product was applied over the culture medium. To perform the analyses, the average percentages were transformed by arcsen $\sqrt{x / 100}$ 
the population in the control poultry house was always significantly higher than that observed for the treated poultry house (Table 4).

Table 4 - Mean numbers ( ${ }$ SEM) of Alphitobius diaperinus per sampling point in poultry houses that were untreated (Control) or treated with the DP cypermethrin-6\% insecticide (Cascavel, Paraná, Brazil).

\begin{tabular}{lcc}
\hline Evaluation & Control Poultry House & Treated Poultry House* \\
\hline Pre-treatment & $6.0 \pm 2.5 \mathrm{aA}(100.0 \%)$ & $9.7 \pm 2.8 \mathrm{aA}(100.0 \%)$ \\
$1^{\text {st }}(15 \mathrm{DAA})$ & $9.8 \pm 3.9 \mathrm{aA}(163.3 \%)$ & $1.5 \pm 0.9 \mathrm{bB}(15.5 \%)$ \\
$2^{\text {nd }}(45 \mathrm{DAA})$ & $13.3 \pm 3.7 \mathrm{aA}(221.6 \%)$ & $1.8 \pm 0.7 \mathrm{bB}(18.6 \%)$ \\
$3^{\text {rd }}(75 \mathrm{DAA})$ & $9.8 \pm 3.2 \mathrm{aA}(163.3 \%)$ & $0.3 \pm 0.1 \mathrm{bB}(3.1 \%)$ \\
\hline
\end{tabular}

Mean numbers $( \pm$ SEM) of individuals at the sampling points and the respective percentages of infestation, in parentheses, relative to the pre-treatment population followed by the same lowercase letter in a column and the same capital letter in a row do not differ by the Wilcoxon test $(p<0.05)$ and the Mann-Whitney test $(p<0.05)$, respectively. * Treatment with the product in the dry powder formulation, applied with an atomizer at $3 \mathrm{~g} / \mathrm{m}^{2}$. Two reapplications were conducted at 30 and 60 days after the first treatment. DAA = days after the first application.

At the first evaluation, performed 15 days after the initial treatment, the lesser mealworm population in the treated poultry house was strongly reduced, by approximately $84 \%$, relative to the pre-treatment population. At the other evaluations $\left(2^{\text {nd }}\right.$ and $\left.3^{\text {rd }}\right)$, the populations of insects were similar and were smaller than the initial population, but no significant difference was observed, even after three applications (75 days).

In the control poultry house, the lesser mealworm population did not differ among the evaluations and was similar until 75 days after the beginning of sampling (Table 4).

\section{DISCUSSION}

Todorova et al. (1998) emphasized that studies evaluating the efficiency and selectivity of chemical products are crucial for the development of Integrated Pest Management (IPM) programs. One of the major issues related to the exclusive and successive use of chemical insecticides is the selection of resistant pest strains (Lacey \& Goetel, 1995).

Resistance of $A$. diaperinus to chemical insecticides, especially pyrethroids and organophosphates, has been reported (Hamm et al., 2006; Lambkin \& Rice, 2006; Tomberlin et al., 2008; Chernaki-Leffer et al., 2011; Lambkin \& Furlong, 2014). Thus, studies monitoring the efficiency of the products used to control the lesser mealworm and aimed at developing alternative control strategies for reducing insect populations are indispensable.

The two formulations of cypermethrin- $6 \%$ showed a similar performance in terms of insect mortality and therefore did not affect the product's activity.
The mortality observed using the cypermethrin-6\% product in the laboratory indicated that it was effective, showing a performance equal or at times superior to (at the lower concentrations) the mortality observed for the cypermethrin-5\% product, which was used as a comparison standard. Cypermethrin- $5 \%$ is one of the most commonly used insecticides in Brazilian poultry houses and contains $1 \%$ less active ingredient (a.i.) in its formulation than the new product. Alves et al. (2010) tested two cypermethrin-based insecticides with a higher concentration (15\% a.i.) in the laboratory and also reported that, at the concentrations recommended by the manufacturers, the products were $100 \%$ effective in causing mortality by contact. Products containing cypermethrin were also tested by Chernaki-Leffer et al. $(2011 ;$ 2012) in Brazilian insect populations, and satisfactory mortality levels induced by direct contact were reported. Additionally, also under laboratory conditions using a cypermethrinbased insecticide, Wolf et al. (2015) obtained mortality values above $93 \%$ for adults.

Tomberlin et al. (2008) tested the mortality of lesser mealworms from poultry houses in the United States in response to four pyrethroid insecticides and reported better performance for a cyfluthrin-based product. Mustac et al. (2013) also studied the efficiency of a cyfluthrin-based product on insects from Croatian poultry houses under laboratory conditions and reported that the populations were highly susceptible to cyfluthrin. However, the aforementioned authors did not test cypermethrin-based products in either of the above studies.

Field studies conducted in other countries have also tested mainly cyfluthrin-based insecticides (Salin et al., 2003; Lambkin et al., 2012). In contrast, studies focusing on broiler houses in Brazil tested cypermethrinbased products (Uemura et al., 2008; Santos et al., 2009; Alves et al., 2010). This difference is explained by the fact that cypermethrin-based products are widely used in Brazil, possibly due to their lower cost, and indicates the uniqueness of each country in the market for insecticides for poultry use.

Santos et al. (2009) reported that a cypermethrinbased insecticide was effective in causing lesser mealworm mortality and in altering the spatial distribution of insects throughout the poultry house. Alves et al. (2010) also tested a cypermethrin-based insecticide and reported control indexes of up to $76 \%$ after 40 days. However, in both cases, an increase in the size of the insect population was observed after a one-flock period (mean of 45 days). The authors performed a single application using the product in 
liquid form for abundant treatment of the soil in the poultry house. This control strategy is recommended because the product reaches insects that bury in the soil to complete their development (Santos et al., 2009; Alves et al., 2010).

This study was conducted in broiler-breeder houses and not in broiler facilities, and it is important to emphasize the lack of field studies conducted under similar conditions. The physical structure of broiler-breeder poultry houses favors pest population management, as they usually have cement floors and curtains sealing the sides and the ceiling. According to Uemura et al. (2008), these characteristics aid lesser mealworm management because they reduce the occurrence of cracks or refuges that benefit the cryptic and escape habits of $A$. diaperinus. In broiler-breeder houses, the health status of the breeders must be better than that of broilers, as they must fertile eggs free from contamination when reaching sexual maturity. Therefore, it is extremely important to eliminate the lesser mealworm or at least to keep its population levels as low as possible, especially in broiler-breeder houses, to prevent the spread of pathogens in the production chain. Thus, the treatment strategy used by Santos et al. (2009) and Alves et al. (2010) was different from the one used in the present study. In this study, the cypermethrin- $6 \%$ product in powder was applied three times on the surface of the poultry litter using an atomizer, at 30-day intervals. This strategy resulted in $96 \%$ reduction in the lesser mealworm populations after 75 days under the evaluated conditions. The higher frequency of insecticide application allows affecting the immature (and most susceptible) insect phases, consequently reducing adult re-infestation in the next cycle.

It is noteworthy that the insects were not completely eliminated from the poultry house even with successive treatments. However, the control index was satisfactory and was well above the minimum $(80 \%)$ indicated by the technical regulations for the licensing of antiparasitic pesticides for veterinary use (Mercosul/GMC, 1996). Environmental management was also considered. Adopting chemical control in combination with alternative management strategies, such as using the fungus $B$. bassiana, could increase the effectiveness of the treatment and possibly reduce the number of chemical applications, thus minimizing the risks of contamination and the selection of resistant individuals (Oliveira et al., 2003; Japp et al., 2010).

Although $B$. bassiana has been identified by several authors as a potential control agent for $A$. diaperinus (Crawford et al., 1998; Geden \& Steinkraus, 2003; Oliveira et al., 2014), its efficiency under field conditions in Brazil was only recently shown (Alves et al. in press). Therefore, there are no available studies evaluating the compatibility of this microbial agent with the chemical insecticides used to control insect populations in Brazilian poultry production systems. The lack of such studies emphasizes the importance of the present study, as it is important to understand the interactions between entomopathogenic fungi and the different chemical products and commercial formulations available.

Because the exposure of the fungus to such products is extreme in compatibility tests in laboratory conditions, when pesticides exhibits high toxicity, the same result may not be necessarily replicated in the field. However, if the product is harmless in vitro, it will certainly be selective under field conditions (Alves et al., 1998a).

The present results showed that the tested chemical insecticide can be considered compatible at all tested concentrations, according to the toxicity classification index proposed by Rossi-Zalaf et al. (2008), despite its negative effects on conidial viability and production. The recommended concentration did not exert a negative effect on the other evaluated parameters of the fungal isolate (CFU and mortality by fungus), indicating that the presence of the product on the surface of the culture medium during germination/ growth did not affect these parameters. Therefore, the cypermethrin- $6 \%$ product may be considered selective for $B$. bassiana under the tested conditions.

Paz et al. (2009) evaluated a product with cypermethrin-5\% that is registered to treat ectoparasites in cattle and obtained different results, with the studied acaricide being classified as toxic to the tested $B$. bassiana isolate. Similar results were found by Barci et al. (2009), who assessed acaricides with different active ingredients, including two cypermethrin-based products with $10 \%$ and $15 \%$ a.i., and reported the products to be toxic to $B$. bassiana isolate IBCB21.

The difference in these results may be linked to the characteristics of each isolate and to the a.i. concentrations of the products tested by the aforementioned authors, as well as to the parameters used to calculate the toxicity index (formula). Moreover, Tamai et al. (2002) noted that chemical products with similar modes of action manufactured by different companies may have different pathogen selection responses due to differences in the ingredients (inert 
ingredients and adjuvants) used in the formulation of each product.

Therefore, based on the results of the present experiment, the application of the DP cypermethrin- $6 \%$ product at $3 \mathrm{~g} / \mathrm{m}^{2}$ on the surface of poultry litter is recommended. The insecticide showed compatibility with the fungus $B$. bassiana (Unioeste 4 isolate) for the control of $A$. diaperinus under in-vitro conditions. Further studies are needed to assess this compatibility under field conditions and to determine the most effective strategy to combine these two agents is.

\section{REFERENCES}

Agabou A, Alloui N. Importance of Alphitobius diaperinus (Panzer) as a reservoir for pathogenic bacteria in Algerian broiler houses. Veterinary World 2010;3:71-73.

Alborzi AR, Rahbar A. Introducing Alphitobius diaperinus, (Insecta: Tenebrionidae) as a new intermediate host of Hadjelia truncata (Nematoda). Iranian Journal of Parasitology 2012;7:92-98.

Alexandre TM, Alves LFA, Neves PMOJ, Alves SB. Efeito da temperatura e substrato sobre Beauveria bassiana e Metarhizium anisopliae e sua relação no controle do cascudinho (Alphitobius diaperinus) (Panzer) (Coleoptera: Tenebrionidae). Neotropical Entomology 2006;35:75-82.

Alves SB, Moino Jr A, Almeida JEM. Produtos fitossanitários e entomopatógenos. In: Alves, SB, editor. Controle microbiano de insetos. Piracicaba: Fealq; 1998a. p.217-238.

Alves SB, Almeida JEM, Moino Jr A, Alves LFA. Técnicas de laboratório. In: Alves, SB, editor. Controle microbiano de insetos. Piracicaba: Fealq; 1998b. p.637-712

Alves LFA, Gassen MH, Pinto FGS, Neves PMOJ, Alves SB. Ocorrência natural de Beauveria bassiana (Bals.) Vuilleman (Moniliales: Moniliaceae) sobre o cascudinho, Alphitobius diaperinus (Panzer) (Coleoptera: Tenebrionidae), em aviário comercial de Cascavel, PR. Neotropical Entomology 2005;34:507-510.

Alves LFA, Neves PMOJ, Oliveira RC, Oliveira DGP. Fatores a serem considerados na utilização de Beauveria bassiana visando o manejo de populações de Alphitobius diaperinus em aviários comerciais. Arquivos do Instituto Biológico 2008;75:13-20.

Alves LFA, Uemura-Lima DH, Oliveira DGP, Godinho RPV. Eficiência de um novo inseticida comercial para o controle do cascudinho dos aviários (Alphitobius diaperinus) (Panzer) (Coleoptera: Tenebrionidae). Arquivos do Instituto Biológico 2010;77:693-700.

Avila VS, Kunz A, Bellaver C, Paiva DP, Jaenisch FRF, Mazzuco H, et al. Boas práticas de produção de frango de corte [circular técnica, 51). Concórdia: Embrapa Suínos e Aves; 2007.

Ayres M, Ayres DL. Biostat 5.3. Belém: Instituto de Desenvolvimento Sustentável Mamiraua; 2007.

Barci AG, Wenzel IM, Almeida JEM, Nogueira AHC, Prado AP. Compatibilidade de isolados de Beauveria bassiana (Ascomycetes: Clavicipitaceae) com carrapaticidas químicos utilizados no controle do carrapato dos bovinos. Revista Brasileira de Parasitologia Veterinária 2009; 18:63-68.

Bates C, Hiett KL, Stern NJ. Relationship of Campylobacter isolated from poultry and from darkling beetles in New Zealand. Avian Diseases 2004;48:138-147.
Bellaver C, Costa CF, Figueiredo EAP, Jaenisch FRT, Fávero JA, Palhares JCP, et al.. Boas práticas de produção de frango [Circular Técnica 38]. Concórdia: Embrapa Suínos e Aves; 2003.

Bicho CL, Almeida LM, Ribeiro PB, Silveira Jr P. Flutuação populacional circanual de coleópteros em granja avícola em Pelotas, RS. Brasil. Iheringia 2005;95:205-212.

Chernaki-Leffer AM, Ishizuca MM, Balieiro JCC, Gorniak SL. The Laboratory efficacy of cypermethrin dust against lesser mealworm larvae and adults, Alphitobius diaperinus (Panzer) (Coleoptera: Tenebrionidae). Journal of Animal Veterinary Advances 2012;13:2215-2219.

Chernaki-Leffer AM, Almeida LM. Exigências térmicas, período de desenvolvimento e sobrevivência de imaturos de Alphitobius diaperinus (Panzer) (Coleoptera: Tenebrionidae). Neotropical Entomology 2001;30:365-368.

Chernaki-Leffer AM, Biesdorf SM, Almeida LM, Leffer EVB, Vigne F. Isolamento de enterobactérias em Alphitobius diaperinus e na cama de aviários no Oeste do Estado do Paraná, Brasil. Revista Brasileira de Ciência Avícola 2002;4:243-247.

Chernaki-Leffer AM, Kuttel J, Martins LM, Pedroso AC, Astolfi-Ferreira CAS, Ferreira F. Vectorial competence of larvae and adults of Alphitobius diaperinus in the transmission of Salmonella Enteritidis in poultry. Vector Borne and Zoonotic Diseases 2010:10:481-487

Chernaki-Leffer AM, Sosa-Gomez DR, Almeida LM, Lopes ION. Susceptibility of Alphitobius diaperinus (Panzer) (Coleoptera, Tenebrionidae) to cypermethrin, dichlorvos and triflumuron in southern Brazil. Revista Brasileira de Entomologia 2011;55:125-128.

Crawford PJ, Brooks WM, Arends JJ. Efficacy of field-isolated strains of Beauveria bassiana (Moniliales: Moniliaceae) as microbial control agents of the lesser mealworm (Coleoptera: Tenebrionidae). Journal of Economic Entomology 1998;91:1295-1301.

Crippen TL, Zheng L, Sheffield CL, Tomberlin JK, Beier RC, Yu Z. Transient gut retention and persistence of Salmonella through metamorphosis in the lesser mealworm, Alphitobius diaperinus (Coleoptera: Tenebrionidae). Journal of Applied Microbiology 2012;112:920-926.

Ferreira DF. SISVAR: a computer statistical analysis system. Ciência e Agrotecnologia 2011;35:1039-1042.

Geden CJ, Steinkraus DC. Evaluation of three formulations of Beauveria bassiana for control of lesser mealworm and hide beetle in Georgia poultry houses. Veterinary Entomology 2003;96:1602-1607.

Godinho RP, Alves LFA. Métodos de avaliação de população de cascudinho (Alphitobius diaperinus) Panzer em aviários de frango de corte. Arquivos do Instituto Biológico 2009;76:107-110.

Hamm RL, Kaufman PE, Reasor CA, Rutz DA, Scott JG. Resistance to cyfluthrin and tetrachlorvinphos in the lesser mealworm, Alphitobius diaperinus, collected from the eastern United States. Pest Management science 2006;62:673-677.

Hazeleger WC, Bolder NM, Beumer RR, Jacobs-Reitsma WF. Darkling beetles (Alphitobius diaperinus) and their larvae as potential vectors for the transfer of Campylobacter jejuni and Salmonella enterica serovar paratyphi B variant java between successive broiler flocks. Applied and Environmental Microbiology 2008;74:6887-6891.

Japp AK, Bicho CL, Silva AVF. Importância e medidas de controle para Alphitobius diaperinus em aviários. Ciência Rural 2010;40:1668-1673.

Lacey LA, Goettel MS. Current developments in microbial control of insect pests and prospects for the early 21st century. Entomophaga 1995;40:1-25 
Lambkin TA. Baseline responses of adult Alphitobius diaperinus (Panzer) (Coleoptera: Tenebrionidae) to fenitrothion, and susceptibility status of populations in Queensland and New South Wales, Australia. Journal of Economic Entomology 2005;98:938-942.

Lambkin TA, Rice SJ. Baseline responses of Alphitobius diaperinus (Coleoptera: Tenebrionidae) to cyfluthrin and detection of strong resistance in field populations in eastern Australia. Journal of Economic Entomology 2006;99:908-913.

Lambkin TA, Furlong MJ. Application of Spinosad increases the susceptibility of insecticide-resistant Alphitobius diaperinus (Coleoptera: Tenebrionidae) to pyrethroids. Journal of Economic Entomology 2014;107:1590-1598.

Lambkin TA, Swain AJ, Rice SJ, Bartlett JS, Zalucki MP. Field assessments of control agents for lesser mealworm (Coleoptera: Tenebrionidae) using litter sampling. Journal of Economic Entomology 2012;105:979-987.

Lopes WDZ, Costa FH, Lopes WCZ, Soares VE, Balieiro JCC, Prado AP. Estudo da sazonalidade de Alphitobius diaperinus em criação de galinhas poedeiras por três diferentes métodos de coleta. Arquivos do Instituto Biológico 2006;73:195-202.

Lopes WDZ, Costa FH, Lopes WCZ, Balieiro JCC, Soares VE, Prado AP. Artrópodes associados ao excremento de aves poedeiras. Neotropical Entomology 2007;36:597-604.

Mercosul/Gmc/Res No76/96. regulamento técnico para registro de produtos antiparasitários de uso veterinário [cited 2014 Out 11]. Available from: http://ftp.unb.br/pub/UNB/ipr/rel/bila/1996/880.pdf.

Mustac S, Rozman V, Škvorc V. Laboratory evaluation of efficacy of several formulations to control the lesser mealworm - Alphitobius diaperinus (Panzer, 1797) (Coleoptera: Tenebrionidae ). Veterinarski Arhiv 2013;83:563-570.

Oliveira DGP, Alves LFA, Sosa-Gomez DR. Advances and perspectives of the use of the entomopathogenic fungi Beauveria bassiana and Metarhizium anisopliae for the control of arthropod pests in poultry production. Brazilian Journal of Poultry Science 2014;16:1-12.

Oliveira CN, Neves PMOJ, Kawazoe LS. Compatibility between the entomopathogenic fungus Beauveria bassiana and insecticides used in coffee plantations. Scientia Agricola 2003;60:663-667.

Oliveira DGP. Proposta de um protocolo para avaliação da viabilidade de conídios de fungos entomopatogenicos e determinação da proteção ao calor conferida a Beauveria bassiana e Metarhizium anisopliae pela formulação em óleo emocionável [dissertation]. Piracicaba (SP): Universidade de São Paulo; 2009.

Pacheco IA, Paula, DC. Insetos de grãos armazenados - identificação e biologia. São Paulo: Fundação Cargill; 1995

Paz Jr FB, Lima EB, Freitas LR, Paz ESL, Queiroz CF. Compatibilidade do fungo Beauveria bassiana com acaricidas químicos usados no controle de Boophilus microplus. Revista de Ciência, Tecnologia e Humanidade do IEPE 2009;1:13-24.

Rohde C, Alves LFA, Neves PMOJ, Alves SB, Silva ERL, Almeida JEM. Seleção de Isolados de Beauveria bassiana (Bals.) Vuill. e Metarhizium anisopliae (Metsch.) Sorok. contra o cascudinho Alphitobius diaperinus (Panzer) (Coleoptera: Tenebrionidae). Neotropical Entomology 2006;35:231240.
Rossi-Zalaf LS, Alves SB, Lopes RB, Silveira Neto S, Tanzini MR. Interação de microrganismos com outros agentes de controle de pragas e doenças. In: Alves SB, editor. Controle microbiano de pragas na América Latina: avanços e desafios. Piracicaba: Fealq; 2008. p.279-302.

Salin C, Delettre YR, Vernon P. Controlling the mealworm Alphitobius diaperinus (Coleoptera: Tenebrionidae) in broiler and turkey houses: Field trials with combined insecticide treatment: insect growth regulator and pyrethroid. Journal of Economic Entomology 2003;96:126-130.

Santos JC, Alves LFA, Opazo MAU, Mertz NR, Marcomini AM, Oliveira DGP, et al. Eficiência da aplicação de inseticida químico no solo para o controle de Alphitobius diaperinus Panzer (Coleoptera: Tenebrionidae) em aviário de frango de corte. Arquivos Instituto Biológico 2009;76:417425.

Segabinazi SD, Flôres ML, Barcelos AS. Bactérias da família enterobacteriaceae em Alphitobius diaperinus oriundos de granja avícolas dos estados do Rio Grande do Sul e Santa Catarina. Acta Scientiae Veterinariae 2005;33:51-55

Silva GS, Veronez VA, Oliveira GP, Borges FA, Silva HC, Meireles MV. Avaliação e métodos de amostragem de "cascudinhos" Alphitobius diaperinus (Panzer) (Tenebrionidae) em cama de frangos de corte. Semina: Ciências Agrárias 2001;22:67-70.

Silva AS, Hoff G, Doyle RL, Santurio JM, Monteiro SG. Ciclo biológico do cascudinho Alphitobius diaperinus em laboratório. Acta Scientiae Veterinariae 2005;33:177-181.

Silva VS, Voss D, Coldebella A, Nelanie Bosetti N, Avila VS. Efeito de tratamentos sobre a carga bacteriana de cama de aviário reutilizada em frangos de corte [Comunicado Técnico, 467]. Concórdia: Embrapa Suínos e Aves; 2007.

Steinkraus DC, Geden CJ, Rutz DA. Susceptibility of lesser mealworm (Coleoptera: Tenebrionidae) to Beauveria bassiana: Effects of host stage, formulation, substrate and host passage. Journal of Medical Entomology 1991;28:314-321.

Tamai MA, Alves SB, Lopes, RB, Faion M, Padulla LFL. Toxicidade de produtos fitossanitários para Beauveria bassaiana (Bals.) Vuill. Arquivos do Instituto Biológico 2002;69:89-96.

Todorova SI, Coderre D, Duchesne RM, Côté JC. Compatibility of Beauveria bassiana with selected fungicide and herbicides. Environmental Entomology 1998;27:427-433.

Tomberlin JK, Richman D, Myers HM. Susceptibility of Alphitobius diaperinus (Coleoptera: Tenebrionidae) from broiler facilities in Texas to four insecticides. Journal of Economic Entomology 2008;101:480-483.

Uemura DH, Alves LFA, Opazo MAU, Alexandre TM, Oliveira DGP, Ventura MU. Distribuição e dinâmica populacional do cascudinho Alphitobius diaperinus (Coleoptera: Tenebrionidae) em aviários de frango de corte. Arquivos do Instituto Biológico 2008;75:429-435.

Wolf J, Potrich M, Lozano ER, Gouvea A, Pegorini CS. Combined physical and chemical methods to control lesser mealworm beetles under laboratory conditions. Poultry Science 2015;94:1145-1149. 
